\title{
Social-scientific criticism: Perspective, process and payoff. Evil eye accusation at Galatia as illustration of the method
}

\author{
Author: \\ John H. Elliott ${ }^{1,2}$ \\ Affiliations: \\ ${ }^{1}$ Department of Theology \\ and Religious Studies, \\ University of San Francisco, \\ United States
}

${ }^{2}$ Faculty of Theology, University of Pretoria, South Africa

Note:

Prof. Dr John H. Elliott is participating as a research associate of Prof. Dr Ernest van Eck, Department of New Testament Studies, Faculty of Theology, University of Pretoria, South Africa. This article is an English version (with minor modifications and additions) of an essay first published in French as 'Lecture socioscientifique. Illustration par l'accusation du Mauvais Oeil en Galatie in Guide des nouvelles lectures de la Bible, edited by André Lacocque (Éditions Bayard, Paris, 2005:141-167). The author would like to express his gratitude to Bayard-Presse for the permission to publish this English version. Space limitations prohibit mention of numerous studies relevant to SSC and the evil eye in the ancient world that have appeared since 2005. Therefore, it was decided to limit this English version to the content of its French counterpart.

Correspondence to: John Elliott

email:

elliottj@usfca.edu

Postal address:

819 Calmar Avenue Oakland, CA 94610-1730, United States

Dates:

Received: 18 May 2010

Accepted: 19 May 2010

Published: 07 June 2011
This article explores a presentation of the method, emergence and contribution of socialscientific criticism (SSC) as an inter-disciplinary operation of New Testament exegesis. A description of ancient evil eye belief and practice and its appearance in Paul's letter to the Galatians illustrates how the method contributes to a more accurate translation of the biblical text, a clarification of its logic and a fuller understanding of the social dynamics involving Paul and his opponents.

\section{Social-scientific criticism: What and why}

Social-Scientific Criticism (SSC) of the Bible is that phase of the exegetical task which analyzes the social and cultural dimensions of the text and of its environmental context through the utilization of the perspectives, theory, models, and research of the social sciences. As a component of the historical-critical method of exegesis, Social-Scientific Criticism investigates biblical texts as meaningful configurations of language intended to communicate between composers and audiences. In this process it studies not only (1) the social aspects of the form and content of texts but also the conditioning factors and intended consequences of the communication process, (2) the correlation of the text's linguistic, literary, theological (ideological), and social dimensions and (3) the manner in which this textual communication was both a reflection of and response to a specific social and cultural context, that is, how it was designed to serve as an effective vehicle of social interaction and an instrument of social as well as literary and theological consequence.

(Elliott 1993:7)

Social-scientific criticism (SSC) is a subdiscipline of exegesis, not a new or independent methodological paradigm. It complements the other subdisciplines of the historical-critical method (text criticism, literary criticism, rhetorical criticism and the like) by bringing socialscientific scrutiny to bear both on texts and on their geographical, historical, economic, social, political and cultural (including 'religious') contexts. The questions it addresses to these twin objects of analysis and the tools of its investigation are those of the social sciences, especially of sociology and cultural anthropology.

SSC is a necessary and indispensable operation of exegesis for several reasons. In general, every writing of the Bible describes events that are social in nature (involving two or more agents), social relations, social structures, social institutions, roles performed and statuses held in the social arena, as well as scripts to be enacted in the social dramas of everyday life. Moreover, each biblical writing is not merely a literary composition but also a social and rhetorical product with literary, theological or social aims. Each is designed to serve as a means of social communication and social interaction and to prompt social action on the part of its targeted audience. Exegesis requires a social-scientific dimension, inasmuch as the biblical texts are both records and products of such sociality.

Biblical texts, like all texts, embed, encode and presume elements of the social and cultural systems in which they are produced, which means that the genre, content, structure and meaning of these texts are all socially and culturally determined. Although some of the social and cultural information is stated explicitly in the text (for instance in Luke-Acts), much - if not most of it - is presumed to be known by its readers (and hearers) and is therefore left unexplained (e.g. in Mark, Philemon or Revelation). Determining the meaning of these texts requires extensive knowledge of the social and cultural systems they presume, that is, on the one hand how these systems are constituted and how they work, how they shape the perspectives, values, interests and aims of the authors; and, on the other hand, how these texts may represent counter-cultural positions. In addition to cultural and social detail identified by exegetical or historical analysis, the social sciences are essential for exploring and explaining the relations and patterns of sociality; the structure and components of social systems; the dynamics of social relations; core cultural values; typical attitudes and perspectives; and prominent social-cultural behavioural scripts. 
How to cite this article: Elliott, J.H., 2011, 'Socialscientific criticism: Perspective, process and payoff. Evil eye accusation at Galatia as illustration of the method', HTS Teologiese Studies/ Theological Studies 67(1), Art. \#858, 10 pages. DOI: 10.4102/hts.v67i1.858
C 2011. The Authors Licensee: OpenJournals Publishing. This work is licensed under the Creative Commons Attribution License.
Given what is now known of how readers (of any historical period) create mental reading scenarios to understand texts, an important task of interpretation is to provide adequate reading scenarios that are culturally appropriate to the texts under consideration. SSC directs attention to these reading scenarios, proposing scenarios whose details are consistent with the cultural and social world of antiquity, whilst criticising scenarios that include details alien to the cultural time and place of the text.

Whilst the descriptions of 'social realia' by self-styled 'social historians' are of interest to all interpreters and readers of the Bible, what is still needed - and what SSC seeks to supply - is a method and a set of models for understanding relations amongst the social phenomena: how they are connected and how they work. Interpretation needs to advance beyond 'social description' to social-scientific analysis and explanation. SSC also differs from 'social historians' by denying the existence of scholarly 'immaculate perception' and theory-free or value-free analysis and by insisting on the explication of all theory and conceptual models used for interpretation. The hypotheses and theories employed by interpreters need to be acknowledged and set out for examination before they can be tested for their 'fit' with the data and evaluated for their interpretive power. SSC is needed for exegesis to move beyond the enlightened 'hunches' of geniuses to analysing theories that can be tested and then reapplied, refined or rejected - by all exegetes alike.

The interest of historians and exegetes tends to focus on what is outstanding or unique about persons, groups or events (for instance about Jesus or Paul; the mode of Christian interaction; the shape of the Q community; or the birth of Jesus). The unusual or singular becomes apparent only once the regularities and recurrences of behaviour and social interaction have been identified. SSC seeks to identify the regularities and recurrences and in the process provide clarity on the unusual or singular.

Exegetes, whilst noting social information in biblical texts, have tended to limit attention to ideas and the realm of theological concepts and thought. What is also needed is a method that considers the relationship between beliefs and behaviours; the relationship between beliefs (and culture in general) and their economic and social Mutterboden; the relationship between ideas and group interests; and the nexus of interests, ideas and ideology. SSC attempts to address these issues both at the level of the text and at the level of the social context (where the clash of rival groups with competing interests, ideas and ideologies comes into view dramatically - as in the case of the Jesus faction and the rival Pharisees or the Pauline Christ movement and the group around James).

Finally, the need for social-scientific criticism is prompted by the fact that all understanding, imagination, expression and communication is socially and culturally conditioned. A method is required to identify and analyse the conditions that have a determinative effect on perception, understanding, imagination, sociality and meaningful communication, as this pertains both to the circumstances of the original communications and to the circumstances of the hearing or reading of these communications in other times and places.

\section{The emergence and development of social-scientific criticism of the New Testament}

Exegesis in the last third of the 20th century has been marked by a growing awareness that the social and cultural contexts of texts and traditions - referred to by historical critics as the Sitze im Leben - needed more refined analysis and articulation. Since the 1970s, more and more exegetes began using social scientific theory for the explication of biblical texts and the social relations described in them. Illustrative and influential works of this initial period include Wayne Meeks on the sectarian perspective of the Gospel of John (1972) and his later treatment of the Pauline mission as an urban phenomenon (1983); Gerd Theissen on the social dynamics concerning the Jesus movement in Palestine and beyond $(1978,1982)$; Fernando Belo on the debt system underlying the Gospel of Mark (1974); John Gager's exposition of the Revelation of John (1975); my examination of First Peter as a product of a sectarian group within Israel with its focus on societal estrangement and group solidarity (Elliott 1981, 1990); and Bruce Malina's delineation 
of characteristic ancient Mediterranean perceptions, values and social strategies $(1981,1986)$. These pioneering efforts - whilst diverse and different in regard to the foci of their attention, the social-scientific research used and their methodologies - established a foundation upon which an ever-growing stream of exegesis along social-scientific lines then built and provided critical and methodological refinement. The relevant bibliography, too exhaustive to provide here, is listed in my 1993 account of the method, What is social-scientific criticism?, in the Fortress Press Guides to Biblical Scholarship series. This volume comprises all the relevant studies through 1992 (pp. 138-174), including a more detailed description of the method (pp. 9-17, 36-86); some of its pioneers and chief practitioners (pp. 17-35); critical assessments of the method (pp. 87-100) and its achievements and contributions (pp. 101-106); appendices (pp. 107-126), including a data inventory for SSC analysis and a list of over seventy interpretive models employed by scholars; a glossary of technical scientific terms (pp. 127-135); as well as the bibliography (pp. 138-174). This remains the most exhaustive description of the method to date.

\section{Selected features of social-scientific criticism}

Social-scientific critics presuppose that all knowledge is socially conditioned and perspectival in nature. Exegesis without social presuppositions is as impossible as exegesis without theological presuppositions. Critics insist that biblical interpretation must involve the clarification both of the social location of the interpreters themselves and of the texts and authors under examination. Social-scientific critics also find it necessary and useful to distinguish 'emic' points of view from 'etic' points of view. Adopted from ethnologists, this contrast distinguishes information and accounts supplied by indigenous informants according to their frameworks of experience, knowledge and rationalisations (emic) from the analytical perspective and categories of the modern investigator (etic). For exegesis, the former applies to the biblical texts and all ancient sources; whilst the latter applies to contemporary readers and scholars. This distinction enables the exegete to remain conscious of the gaps separating the modern scholar from the world and literary productions of the ancient cultures under examination. This in turn prompts the interpreter to consider the 'plausibility structures' that lend credence to beliefs and concepts striking moderns as 'unscientific' or 'superstitious' or merely bizarre. The distinction also helps to minimise anachronistic and ethnocentric readings and evaluations of ancient texts. It further serves to limit an overly eager application of ancient biblical texts to modern ethical issues and to critique inappropriate ascription of modern perspectives and values (such as universal freedom and equality) to the decidedly non-egalitarian societies of the ancient world, including the Jesus movement.

Proceeding from the conviction that there is no such thing as 'immaculate perception', social-scientific critics indicate,

1.For such a critique see Elliott (2002 and 2003). usually at the outset, the hypotheses and conceptual models shaping their investigation of texts or social contexts. The method proceeds from hypotheses, theory and models to data collection, analysis and, finally, interpretation and explanation. Technically speaking, data are products (lit. 'givens') of hypotheses about the nature and relation of phenomena; data are not the raw phenomena themselves. In SSC, hypotheses about the nature and relation of specific social phenomena are set out in conceptual models. These models are simplified, abstract representations of prominent features of related social phenomena. They function as the analytical lenses and cognitive maps by which we view, filter and organise into meaningful patterns the raw material available to our senses. We use sociological models to detect and connect 'social dots', as it were, on the textual and cultural landscapes and assess their social significance and impact. In the investigation of ancient texts or their social contexts, conceptual models are operative, whether acknowledged or not, in every description of 'how things were', 'how things were related' and 'how they worked'. The question is not 'who uses models and who does not?' but 'who makes them explicit and who does not?' Hypotheses and models left unclarified and even unrecognised by those claiming some kind of 'objectivity' result in hunches that cannot be tested for their fit with the data nor assessed for their explanatory power. $^{2}$

On the one hand, social-scientific critics differ fundamentally from self-styled 'social historians' who claim methodological 'objectivity', eschew theory and models as 'cookie-cutter' devices, and leave their own conceptual models and assumed social scenarios unstated and therefore inaccessible to evaluation and testing. On the other hand, hypotheses, models and scenarios that have been made explicit can then be tested, refined or abandoned according to their fit or lack of fit with the available data.

Social-scientific critics seek to make manifest social arrangements and cultural values and norms that were latent in the ancient texts but not expressly stated, in order to make the thought of the text or the processes of everyday life more comprehensible. In a related vein, the critics reckon that in the ancient world 'religion', like economics, was not an independent, free-standing institution as in modern societies, but, like economics, was embedded in each of the two major institutions of the polis and the oikos, the city and the household. Like the text they investigate, these critics speak little of 'religion' as such, but rather of political religion or domestic religion; and religion shaped by contrasting structures, values and norms of political life, on the one hand, or domestic life, on the other.

Comparison of biblical cultures to those of other traditional, pre-Enlightenment societies reveals structural and behavioural similarities and regularities, as well as regional and historical differences. Knowledge of both similarities

2.For a fuller discussion of models see Elliott (1986:1-33 and 1993:40-48) and Esler (2006). 
and peculiarities is essential for determining the patterns of belief and behaviour found in the biblical communities and their writings. 'Like detectives, interpreters of historical cultures are better equipped to decipher cultural traces the more exposure they have to different kinds of cases,' $\mathrm{H}$. Eilberg-Schwartz (1990:238) aptly observed.

The variety of social or cultural issues analysed, including their scope and complexity, account for the diversity of conceptual models and their variation in scope (from macro to mid-range and to micro levels) and abstraction. Some scholars have focused on broad, encompassing topics requiring models sufficiently abstract in level and designed for cross-cultural comparison such as the moral economy of peasants, studies on cultural perceptions (e.g. 'limited good'), values (e.g. honour and shame, generosity), concepts of group identity and dyadic personality, gender constructs, kinship and fictive kin relations, perceptions of illness and related methods of healing, as well as social strategies (comparative marriage strategies; establishment of patronclient alliances), typical of the ancient Circum-Mediterranean region as a whole. Mid-range analysis has examined particular economic or social institutions (Jerusalem Temple purity and debt system; Galilean fishing industry), the formative Jesus movement as a faction and then sect of Israel and specific regions of the Mediterranean world such as Egypt or Roman-occupied Palestine, or Corinth or Philippi as Roman colonies. Micro-level analyses have investigated social-stratification issues at Corinth and in the Corinthian correspondence; Jesus and opponents in challenge-riposte engagements (the so-called conflict stories of form criticism); insider-outsider conflicts in Galatia or Asia Minor; or events of an altered state of consciousness as experienced by Jesus or Paul or the Seer of Patmos. ${ }^{3}$ The types of models found heuristically useful for these three levels of analysis are listed in Elliott (1993:64-66, 124-126).

\section{A focus on biblical texts}

The foregoing issues concern broad social structures and cultural patterns of thought and behaviour that form the context of the biblical writings. Elements of these are encoded in the texts themselves. A second major focus of SSC is the biblical writings themselves, their reference to specific sets of values, modes of social interaction or their social situations and strategies for serving as effective means of social communication and interaction. Representative of such textoriented, exegetical investigations informed by the social sciences are inter alios the monographs of B. Malina-J. Neyrey (1988) and J. Neyrey (1998) on Matthew; F. Belo (1974), J. Wilde (1974) and H. Waetjen (1989) on the Gospel of Mark; P. Esler (1987), H. Moxnes (1988), D. Gowler (1991) and J. Neyrey (1991) on the Gospel of Luke; S. Guijarro Oporto (1998) and B. Malina-R. Rohrbaugh (1992) on the Synoptics; J. Neyrey (1988), A. Blasi (1996), B. Malina (1985), B. Malina-R. Rohrbaugh (1998) and A. Destro-M. Pesce (2000) on the

3.John Pilch has written extensively on altered states of consciousness; see especially Pilch (2004).
Gospel of John; J. Kloppenborg on Q (2000); J. Neyrey (1990) on Paul; J. Pilch (1983) and P. Esler $(1998,2003)$ on Galatians and Romans; G. Theissen (1982) and D. Gordon (1997) on the Corinthian correspondence; N. Petersen (1985) on Philemon; J.H. Elliott $(1981,1990)$ and B. Campbell (1998) on 1 Peter; and J. Gager (1975), B. Malina (1995) and B. Malina-J. Pilch (2008) on the Revelation of John. Here a variety of theory and analytical models have been employed to clarify the features of the rhetorical situation and actual life context of these writings and the factors shaping their response (insideroutsider conflict; issues of social formation, identity, cohesion and boundaries; sectarian perspectives and strategies; pivotal cultural values; theologies or ideologies linked to specific interests). Consequently both texts and the culture at large, along with the nature of their interrelatedness have been subjected to social-scientific scrutiny. As social-scientific critics recognise the variety of perspectives, experiences and social locations shaping the choice of objects for analysis and the hypotheses employed, many of their studies are the result of team research and collaborative publication, as illustrated by numerous publications of the Context Group. ${ }^{4}$

\section{The interpretive payoff}

The 'payoff' from this incorporation of SSC into the toolkit of the historical-critical method has been impressive. Attention is finally being given to the social and cultural contexts of the biblical writings that were previously analysed predominantly for their theological and ideational content. Identification and elaboration of the social institutions presumed yet rarely fully described in the texts (kinship and fictive kinship; patronage and clientism; differing modes of economic and social exchange, etc.) are a further boon. The cultural values influencing the behavioural scripts described or called for in the biblical writings are also emerging into clearer light. ${ }^{5}$

Social-scientific critics have shown how awareness of belief complexes typical of the ancient Circum-Mediterranean (such as belief in demons and spirits as causing illness and the practice therefore of exorcism as a plausible means of healing, along with the social ramifications of this belief) allows the interpreter to detect in texts the presence and impact of such beliefs when only the tip of the belief 'iceberg' is in view. Or to change the metaphor, familiarity with such belief complexes will enable the exegete not only to spot telltale 'dots' in a text, but also to connect these dots and produce a coherent explanation of their interrelation and significance.

Social-scientific critics have also demonstrated the importance of considering and ascertaining the group interests prompting each of the biblical writings, the interrelation of group interests, theology and ideology and the relation of complexes of belief to patterns of behaviour.

4.For publications see the Context Group Website (http://www.contextgroup.org).

5.For the relevant literature throughout 1992 see Elliott (1993:138-174). For 1992-2004 my personal list (unpublished) of relevant publications contains 328 titles; see also the bibliographies in Blasi, Duhaime and Turcotte (2002:643-703, titles; see also the bibliographies in Blasi, Duhaime and Turcotte (2002:643-703,
707-751). For more recent overviews of research developments along SSC lines see Elliott (2008a, 2008b). 
Through sensitivity to the different 'social and cultural locations' separating modern readers and scholars from ancient authors and their communities, SSC assists a reading of the biblical writings as reflections and products of ancient rather than modern thought, attitudes and values. In clarifying the theory, premises and scenarios which each interpreter brings to the reading of ancient documents, SSC helps modern readers navigate the distortions of an anachronistic and ethnocentric reading of the Bible. It also helps to prevent the misuse of the Scriptures as a moral hammer or sword in current ethical debates by showing that certain perceptions and premises underpinning ancient moral standards and laws are no longer shared. The biblical rules as such lack a plausible conceptual foundation and hence are no longer judged relevant to contemporary life.

After a quarter century the debate concerning SSC continues as the method itself undergoes refinement. The corpus of research that is justly labelled SSC and its positive assessments, including those of sociologists, ${ }^{7}$ bear eloquent witness to its enthusiastic reception not only amongst exegetes and ancient historians, but also amongst clergy and general readers.

\section{Text in its cultural context}

I have provided a brief description of the SSC method for analysing a text and determining its social situation and rhetorical strategy in What is social-scientific criticism? (1993:70-86). A more comprehensive demonstration in practice appears in my analysis of First Peter, A home for the homeless $(1981,1990)$. To illustrate a second focus of SSC - the social and cultural contexts of the biblical writings as they bear on these writings - I shall now turn to a prominent feature of Circum-Mediterranean culture: the ubiquitous belief in the evil eye and its assumed power to injure and destroy. After reviewing the key features of this belief and its related apotropaic practice, consideration will be given to elements of this belief complex in Paul's letter to the Galatians and the role evil eye accusations played in the interaction of the apostle with his Galatian opponents.

\section{Evil eye accusations in Galatians as illustration}

The focus of attention now shifts to Paul's mention of the evil eye in his letter to the Galatians, its meaning, rhetorical function and social ramifications. Modern translators of the Bible tend to obscure the evil eye references in the original languages, whilst contemporary commentators generally fail to recognise the numerous biblical references to this prevalent ancient belief, let alone explain their meaning and social implications. The text of Galatians is no exception. A summary of salient features of evil eye belief and practice (EEBP), as identified by classicists, historians and anthropologists, will provide the contours of a theoretical model for tracking manifest and latent references to the evil eye in Galatians and explaining their social ramifications. This involves elucidating aspects of Galatians generally unseen or ignored in contemporary exegesis of this letter.
Why did Paul, in his letter to the Galatians, say that on his first visit to the Galatians they did not spit (exeptysate, Gl 4:14a)? Most modern Bible versions do not translate this verb as 'spit,' but rather as 'despise' (KJV, RSV) or 'show contempt' (BJ, NEB). Why is that? What motivated Paul's strange claim that the Galatians would have 'torn out your eyes and given them to me' (4:15)? Why was envy such a concern in this letter, especially where Paul depicts his readers as 'children' (4:17-20; cf. also 3:23-4:7)? What connection do these points have with Paul's explicit reference to injury through an evil eye in Galatians 3:1? Why is ebaskanen, a form of the standard Greek verb for 'injure with an evil eye', not translated as such in modern Bible versions and commentaries (though it was in earlier time)? What belief complex and associated practices did this verb represent to Paul and his intended audience? To what form of social interaction could these phenomena be pointing? What social dynamic comes into view when investigating and associating these issues?

\section{Evil eye belief and practice in the ancient Circum-Mediterranean}

In order to answer these questions (that a social-scientific approach to this text raises), some basic information on evil eye belief and practice (EEBP) is essential. ${ }^{6}$

The evil eye belief entails the notion that the eye of a person can be so powerful that a mere glance from it could injure, destroy or kill any human, animal or thing struck by such a glance. Evil eye practice involves all strategies and devices used to ward off, deflect or overcome damage from an evil eye. Along with belief in deities and demons, belief in the existence and destructive power of the evil eye pervaded the Ancient Near East and Circum-Mediterranean. To the malevolent working of the evil eye demon or to humans possessing an evil eye were attributed throughout the ancient world sudden illnesses, injuries, loss of children and family, death of cattle, outbreaks of war and social conflict and other disasters.

Attested in Sumerian incantations as early as 3000 BCE, the evil eye belief spread from Mesopotamia, its suspected point of origin, to India and then westward throughout the Circum-Mediterranean, northward to Europe and eventually from 'old' to 'new' worlds. Whilst not a universal phenomenon, this belief was found in 67 of 186 different societies worldwide (Roberts in Maloney 1976:229-234) and today appears to be known around the globe. Dread of the evil eye pervaded Mesopotamian, Egyptian, Greek and Roman cultures (Elliott 1991; Rakoczy 1996) and references to the evil eye appear frequently in Old and New Testaments (Elliott 1988, 1990, 1992, 1994). Here mention of the evil eye is found in connection with scarcity and famine, meals, social encounters, moral behaviour, the source of evil, miserliness, greed and envy in particular (see Dt 15:9, 28:54, 56; Pr 23:6;

6.From the comprehensive literature see Jahn (1855); Elworthy (1895); Seligmann (1910, 1922, 1927); Ebeling (1949), Gifford (1958), Noy (1971); Maloney (1976); (1910, 1922, 1927); Ebeling (1949), Gifford (1958), Noy (1971); Maloney (1976);
Dundes (1981/1992); Elliott (1988, 1990, 1991, 1992, 1994); Rakoczy (1996); Ford (1998). Additional literature in the bibliographies of the Elliott articles. 
28:22; Sir 14:3, 6, 8, 9, 10; 18:18; 31:13; 37:11; Wis 4:12; Tob $4: 7,16)$. EpJer 69, 70 mentions an amulet (probaskanion) used to protect a cucumber field from the withering glance of an envious evil eye. 'What has been created more evil than an Evil Eye?' laments the Sage (Sir 31:13). In the New Testament, in addition to Galatians 3:1, three evil eye sayings are attributed to Jesus. One contrasts an evil eye to a sound eye (Mt 6:22-23; Lk 11:33-34); another involves an implicit evil eye accusation (Mt 20:15), whilst a third links the evil eye to the heart (Mk 7:22). Implicit references to the evil eye have been suspected in passages referring to envy, hatred, greed or covetousness of eye or heart (e.g. Gn 4:5; 30:1; 37:11; Ex 20:17; 1 Sm 2:32; 18:8-9; Ps 73:3; Pr 23:1; Jr 22:17) or to apotropaic amulets (Jdg 8:21, 26; Is 3:20) customarily employed against the evil eye. The translations of evil eye texts in modern Bible versions leave readers with the misimpression that the Bible contains no mention whatsoever of this ubiquitous belief. Although documented and extensively studied by historians, archaeologists, classicists, ophthalmologists and anthropologists, EEBP is rarely examined or even mentioned by biblical scholars.

The Hebrew expression for evil eye is ra' 'ayin, 'ayin hara'. The extensive semantic field in Greek involves terms of the bask-root, the most important ones being baskainô (injure with an evil eye), baskanos (one who possesses or casts an evil eye), baskanon (an apotropaic device warding off the evil eye, especially a figure of phallus and testicles) and baskania (the phenomenon of the evil eye). Further expressions include ophthalmos ponêros or ophthalmos ponêros phthoneros (envious evil eye). The equivalent expressions in Latin are oculus malus or oculus malignus or oculus invidus or oculus nequam or oculus obliquus. An even more frequent set of Latin terms are those that simply Latinise words of the Greek bask-family, thereby producing fascino for baskainô, fascinator for baskanos, fascinum for baskanon and fascinatio for baskania. Therefore to 'fascinate' is actually to 'injure with the evil eye'. In Latin the conventional association of evil eye with envy becomes even more explicit. The word for 'envy', invidia, is a composite of in + videre and literally means 'to over-look'. Consequently invidia or envy involves the notion of 'looking over' something or someone with the desire to damage or destroy it.

Certain ecological, economic and social conditions provided the seedbed for EEBP and the structures that made it plausible. ${ }^{7}$ EEBP has thrived in small-scale, face-to-face communities marked by competition over scarce resources, economic disparity, social stratification, concern over social boundaries and where centralised authority for the adjudication of conflicts generally is lacking, unenforced or ineffective. The image of 'limited good', so typical of such 'agonistic' peasant communities (Malina 2001:81-107) - the presumption, namely, that all goods and resources were in limited and scarce supply so that your gain could come only at my loss - was consistent with such competition and fuelled feelings of envy toward successful rivals. The 'ocular aggression' that also typifies Circum-Mediterranean culture,

7.See especially Maloney (1976:223-278, 287-328) with its taboo on glaring and staring, accounts in part for evil and malicious intent being connected to the eye in particular. With the eye also thought to be linked directly to the heart, the seat of thought and disposition, the eye was seen as a channel to and reflection of, the heart and its dispositions, wholesome or evil. Evil thoughts of the heart and in particular envy and malice were manifested and projected by an evil eye. Until the 1500s the eye was regarded as an active rather than a passive organ and was thought to emit or cast rays or emanations that were charged positively or negatively with the good or evil dispositions arising in the heart. The 'Table Talk' of Plutarch (Quaest. conv. 5.7, Mor. 680C-683B) provides an instructive and rare emic discussion of this ancient ocular theory and how the evil eye strikes its victims.

Possessors or 'casters' of the evil eye (jettatori in Italian), it is believed, have telltale, ocular peculiarities ranging from blindness in one or both eyes to ocular impairment (crossed eyes, squinting eyes, wandering eye, eyes with double pupils), sunken eye sockets, or even bushy eyebrows that meet. Disfigured, deformed and socially deviant persons were also suspected of possessing and casting the evil eye, as well as people with epilepsy, all strangers and any others who because of their perceived deprivations might have reason to envy the well-being, success and good fortune of others.

As to the victims of the evil eye, humans, animals, entire households and even inanimate objects, they were all considered vulnerable to attack. Children and specifically babies were thought particularly at risk because of their weaker constitutions. Their breast-feeding mothers were also deemed vulnerable.

Notions passed on by Pliny the Elder concerning certain exotic peoples of his day illustrate several of these features:

Isogonus and Nymphodorus report that there are families in the same part of Africa that injure by the evil eye (effascinantium), whose praises cause meadows to dry up, trees to wither and infants to perish. Isogonus adds that there are people of the same kind among the Triballi and the Illyrians, who also injure by the evil eye (effascinent) and who kill those at whom they stare for a longer time, especially with furious eyes (iratis oculis) and that their evil eye (malum) is most felt by adults; and what is more remarkable is that they have two pupils in each eye.

(Natural History 7.2.16-18)

For warding off the evil eye a vast arsenal of amulets, gestures, devices and expressions were used. Amulets were worn, displayed on the exterior of houses or the interior of shops, or erected on thoroughfares. Protective manual gestures included the mano fica (fist with thumb inserted between first and second fingers), the mano cornuta (fist with first and last fingers extended horizontally) or the digitus infamis (extended middle finger, similar to the North American 'high sign' or 'bird'). In addition there were verbal spells, incantations and words of power. One frequent stratagem was to spit three times in the presence of a suspected evil eye possessor, a measure often used in the protection of babies and children (Theocritus 6.39; 20.11; Pliny, Natural History 28.39). Such 
apotropaic spitting deserves particular attention as it appears in Galatians, as we shall see, along with the mention of eyes, victimised children, envy and explicit reference to injury by an evil eye.

As fear of evil-eyed persons was so constant, being accused of possessing and casting an evil eye had disastrous consequences for the persons accused (and for their families and associates), their public standing and their social relationships. Employed in small, face-to-face groups where central authority and control was lacking or ineffective and where disputes were settled in the court of public opinion, evil eye accusations that were given credence and made to stick exposed the accused to the fear (and often loathing) of neighbours, public shaming, loss of credibility and status and social avoidance or ostracism. An accused person had to reject and disprove the charge or suffer the shameful and destructive consequences. This factor too is highly relevant to the social dynamic implied in Paul's letter to the Galatians.

\section{Evil eye accusations at Galatia}

When we read Galatians against the background of this profile of evil eye belief and practice, the conflict apparent in the letter assumes a new and fascinating social dimension. Accompanying the theological contention over Torah observance, commensality, circumcision, calendar, belief in Jesus as the Christ, divine favour and salvation as justification, is a social battle in which both conflicting parties resort to evil eye accusations designed to discredit and disarm their rival. ${ }^{8}$ EEBP belonged to the tradition known to Jesus and Paul and remained a component of both Jewish and Christian culture through late antiquity and beyond. It flourished in all areas of Paul's activity, Galatia in particular. As Graydon Snyder (2002) has shown recently, EEBP thrived amongst the Celts both ancient and modern. It was most likely Galatai (Gauls or Celts) from Asia Minor, who, in their migrations westward, helped spread EEBP to Galicia in Spain and then northward to the Gaelic peoples of Ireland and Scotland where dread of the evil eye and strategies for counteracting it carried over into modern time. The evil eye, in other words, was thoroughly familiar to Paul and to his Galatian hosts.

The rhetorical question of Galatians 3:1 is the first explicit indication that the evil eye is an issue for Paul and the Galatians. 'O Galatians,' Paul asks rhetorically, 'who has injured you with an Evil Eye (tis hymas ebaskanen), you before whose very eyes Jesus Christ was proclaimed as justified?' The verb baskainô is the standard Greek term for 'cast an evil eye' or 'injure with an evil eye' (BDAG 171), a fact regularly overlooked or obscured by virtually all contemporary commentators and most modern Bible versions. Renditions such as 'who has bewitched you' (Luther, KJV, RSV, NRSV, NEB) or 'who has put or cast a spell on or over you' (NAB, NJB) do not communicate to modern readers the factor of the evil eye entailed in baskainô and its paronyms (baskanos, baskania, baskanon, probaskanon). As a consequence, modern

8.On the situation and strategy of Galatians in general see P. Esler's study along socialscientific lines (1998).
Bible readers fail to learn that Paul is referring here to the dreaded evil eye. J.B. Lightfoot's translation (1892), 'who has fascinated you', reflects evil eye terminology and echoes Jerome's rendition (quis vos fascinavit). But Lightfoot failed to explore the connection of Galatians 3:1 to other traces of evil eye belief in the letter. Contemporary commentators appear unfamiliar with the language of EEBP altogether. ${ }^{9}$

An SSC analysis that examines Galatians according to a model constructed of salient features of EEBP, not only detects several other traces of the belief, but also 'connects these dots' and illuminates an important social dimension of the Galatian conflict and of Paul's social and rhetorical strategy. Besides the verb baskainô (Gl 3:1), the following items also form part of the evil eye belief complex in Galatians:

- Paul's repeated reference to 'eyes' [ophthalmoi] with no mention of ocular aversion (a customary anti-evil eye tactic). Before their eyes, he stresses, he publicly portrayed Jesus Christ as crucified (3:1b), with nothing about their averting their eyes. On their first meeting, he recalls, they were prepared, to tear out their very eyes and give them to Paul (4:15).

- When the Galatians first met Paul, he further recalls, they were not put off by his physical condition (4:13-14) nor did they 'spit' ([ouk exeptysate], 4:14) in his presence-two reactions to be expected of persons fearing strangers and physically disabled persons as potential possessors and casters of the evil eye. To the contrary, they received him not as a bearer of evil but 'as an angel of God, as Christ Jesus' (4:14b).

- As noted by ancient commentators, Paul's reference to the Galatians as 'little children' (tekna, 4:19cf. 3:23-4:7) is significant, given the fact that children were thought particularly vulnerable to evil eye attack.

- The repeated emphasis on envy here (zêlousin, zêloute, zêlousthai, 4:17, 18) and elsewhere in the letter (zêlos, 5:20; phthonos, 5:21; phthonein, 5:26) is likewise noteworthy, because envy is the malignant disposition most often associated with an evil eye. ${ }^{10}$ An evil eye actualises and externalises this envy. Esler (1998:227-230) is one of the few recent commentators aware of this association of envy and the evil eye.

- These various factors associated with EEBP, together with his invocation of a curse upon his opponents (anathema, $1: 8,9$ ) and his censure of 'sorcery' (pharmakeia, 5:20), give evidence of the cultural and conceptual world of the apostle as one in which evil eye belief and accusation is fully at home.

Viewing this collection of data against the background of the evil eye model allows for positing the scenario that follows. Paul's explicit reference to the evil eye in this letter (G1 3:1)

9.Snyder (2002:27) is a rare and welcome exception. He translates Galatians 3:1: 'You foolish Celts! Who has given you the evil eye?' See also Malina-Pilch (2006:202-203, 209-210, 359-362).

10.Envy is the displeasure felt at the successes and good things of one's rivals and the wish that they be deprived of them (see Aristotle, Rhetorica 2.11, 1387b-1388a). Jealousy, on the other hand, is fear of losing what one already possesses. It is the Jealousy, on the other hand, is fear of losing what one already possesses. It is the
former, rather than the latter, of which Paul speaks in Galatians. It is also envy, not former, rather than the latter, of which Paul speaks in Galatians. It is also envy, not
jealousy that is regularly linked with the Evil Eye. See also Helmut Schoeck (1970). 
indicates that it was a specific issue of importance in his relations with the Galatians. More specifically, the details included in his description of his initial encounter with the Galatians (4:12-15) form part of a defence Paul mounts against an accusation that he was an evil-eyed stranger intent on injuring the Galatians and harming their collective well-being. His opponents, besides challenging his gospel and its novel social implications, sought to undermine him personally by labelling him an accursed evil eye possessor.

It may also be that Paul's 'physical ailment' which, he conceded, first was a 'trial' to the Galatians (4:13-14), together with the 'marks' (stigmata) on his body (6:17), which he curiously and abruptly mentions at the very close of the letter (6:17), were the physical features that his opponents pointed to as telltale evidence supporting their evil eye accusation. This is likely when we recall that infirmity, deformity, blindness and epilepsy - all suspected at one time or another as the nature of Paul's ailment - were for the ancients concrete evidence of a person being an evil eye possessor. According to one Pauline tradition, Saul (Paul) once was struck with temporary blindness (Ac 9:1-19), perhaps resulting in some form of permanent eye impairment. The fact that the Galatians were ready to tear out their own eyes and give them to Paul (4:15) could relate to at least some kind of ocular impairment on Paul's part that they had hoped to overcome. The first physical description given of Paul, the Acts of Paul and Thecla (3:2), mentions another remarkable ocular feature of Paul - the fact that his eyebrows were bushy and met above his nose. This, along with blindness, is a further characteristic of evil eye possessors and another detail linking Paul to the evil eye in Pauline tradition. What these references to various features of Paul's physical appearance have in common is that they all concern features associated with the evil eye. Could it be that they also represent memories of Paul's once having been accused of casting an evil eye?

Whatever the answer to this intriguing question, it appears in any case that in Galatians Paul mounts a defence against the charge that he is an evil eye possessor out to ruin the Galatians. This damaging accusation could not be left unchallenged. If he did not disprove it, Paul (and his associates) would be publicly disgraced and degraded and dreaded as a danger to the health and well-being of the Galatian community. His credibility would be undermined and his proclamation dismissed as deceptive and self-serving. Therefore, if Paul's entire mission and message in Galatia were not to be discredited and dismissed, he had to respond to this serious charge and prove it false.

Paul's response to the accusation is twofold. Firstly, he disproves the allegation by reminding the Galatians of the cordial relations that prevailed at their initial meeting. Their unguarded reception of him (though a stranger with a manifest physical malady and striking markings on his body), their not averting their eyes from him, their not spitting in his presence, their willingness, in fact, to give him their own eyes, their embracing him as a messenger of God - all these details indicate that the Galatians did not, at any time, regard him as a hostile and envious fascinator intent on their injury. This defensive manoeuvre is accompanied by an offensive attack. Secondly, Paul reverses the tables and, counters the evil eye attack of his opponents with an evil eye accusation of his own: 'It is not $\mathrm{I}$,' he implies in the rhetorical question of 3:1, 'who injure you with an Evil Eye; it is rather my very accusers.' 'It is they who are harming you with their malice and envy' (4:17). 'It is they who are taking advantage of you as children in faith' (cf. 4:19). 'It is they who are envious of your liberty and exploit you for their own self-seeking purposes and exclude you from the household of faith' $(4: 17 ; 6: 12-13)$. 'It is they whose Evil Eye and envy engenders dissension within the community' (5:19-21, 26), '.. in contrast to my gospel of liberty and love in the Spirit' (5:1-6:16). 'It is they, preoccupied with physical appearance, circumcision, and bodily stigmata, who reveal themselves as slaves of the flesh rather than children of the Spirit' $(5: 2-26 ; 6: 11-15,17)$. 'It is they and their alien gospel that are accursed' $(1: 6-9 ; 3: 10)$.

\section{The evil eye in Galatians - A summary}

Our consideration of a potent belief complex in Paul's world and the presence and role of this belief complex in Galatians have shown that the conflict in which Paul and his opponents were engaged not only involved theological debate over divine grace, Jesus as Messiah, Torah observance, freedom and life animated by the Spirit of God, but also a battle over the more mundane issue of evil eye possession and those who had the Galatians' interests at heart. In this struggle for the 'hearts and minds' of the Galatians, Paul's rivals challenged him in the court of public opinion and sought to discredit him as a dangerous evil-eyed stranger intent on grievously harming his Galatian hosts. Paul defended himself against this charge and turned the tables on his accusers, claiming that it was they and not he who were exploiting and injuring the vulnerable Galatians with their Evil-eyed malice.

In methodological terms the Galatian 'Textprobe' indicates how a model of a particular belief complex and its associated practices and social implications can be used as a heuristic means of probing the social contours of literary texts. Elements of EEBP that are documented in the literature, inscriptions and material artefacts of the ancient Mediterranean region have been brought together to construct a composite sketch of this belief and its associated practices. From this summary a heuristic model has been constructed that serves:

- to alert the readers of Galatians to the great prominence of EEBP in Mediterranean antiquity, including the world of Paul and the Galatians

- to identify manifest and latent references to EEBP in Galatians

- to show the meaningful relation of all these references and 'connect the dots' as it were

- to identify and explain the social dynamic to which these evil eye references point

- to show the coherence of this dynamic with broader features of this writing, its situation and socio-rhetorical strategy.

Most modern biblical translations and commentaries, perhaps because of their being unacquainted with this ubiquitous 
belief, make no explicit mention of the evil eye or spitting in their renditions of Galatians. As a consequence, general readers are left uninformed and exegetical experts fail to see, connect and explain the dots. On the other hand, reading Paul's actual words in the light of this widespread concept and its practice brings new light to bear on the argument of Galatians and on a dynamic of accusation and counteraccusation concerning one of the most dreaded powers in the ancient world.

\section{Social scientific criticism - the payoff}

The payoffs of a social-scientific analysis of ancient biblical texts and their social and cultural contexts include a fuller understanding of the meaningful communication of the biblical texts in their original settings; a fuller understanding of the structure and regularities of ancient social life and interaction; a fuller understanding of the values, attitudes and expectations that inform discourse and action; and a fuller understanding of the inseparable interrelation of patterns of beliefs and patterns of behaviour, the interconnections of interests and ideology. As such, SSC sheds more light on the actual lived experience of the ancient biblical communities. At the same time, SSC aims to influence the way in which the Bible is used today as a source of inspiration and moral guidance, by directing the attention of current readers to these same issues of the interrelation of patterns of belief and patterns of behaviour, interests and ideology, message and matrix.

\section{Acknowledgement}

I first met our honouree, Andries van Aarde, when he and colleagues Piet van Staden, Jan Botha, Fika van Rensburg, Willem Vorster, Jacques Rousseau, Jannie Smits and Bernard Combrink hosted my lecture tour to South Africa in June 1990. At the time, Mr Nelson Mandela was visiting my home in the United States and addressing the United Nations Special Committee Against Apartheid. A new transformative era was dawning in South Africa. For the churches and academia, from my perspective, this monumental turning point involved moving toward a genuine contextualisation of modern and biblical theology (historically, economically, socially, politically, culturally and religiously). My lectures were aimed at demonstrating a method for interpreting the biblical writings that merged the disciplines of exegesis and the social sciences in order to contextualise these writings in their proper settings Andries was one of many of my South African hosts who realised the merit and urgency of this undertaking. I hope our honouree finds the following essay an appropriate expression of our common commitment to contextualisation - of the Bible and of today's gospel of justice and reconciliation.

\section{References}

Belo, F., 1974, Lecture matérialiste de l'évangile de Marc: Récit-Practique-Idéologie [A Materialist Reading of the Gospel of Mark], Cerf, Paris, 2nd rev. edn., 1975, English translation, 1981.

Blasi, A.J., 1996, A sociology of Johannine Christianity, Texts and studies in religion, 69 Edwin Mellen, Lewiston, New York.
Blasi, A.J., Duhaime, J. \& Turcotte, P. (eds.), 2002, Handbook of early Christianity: Social science approaches, AltaMira Press, Walnut Creek.

Campbell, B.L., 1998, Honor, shame, and the rhetoric of 1 Peter, SBLDS 160, Scholars Press, Atlanta.

Coleman, J.A., 1999, 'The Bible and sociology - 1998 Paul Hanly Furfey Lecture', Sociology of Religion 60(2), 125-148.

Destro, A. \& Pesce, M., 2000, Come nasce una religione: Antropologia e esegesi del Vangelo di Giovanni, Laterza, Rome/Bari.

Dundes, A. (ed.), 1992, The evil eye: A folklore casebook, rev. edn., University of Wisconsin Press, Madison.

Ebeling, E., 1949, 'Beschwörungen gegen den Feind und den bösen Blick aus dem Zweistromlande', Archiv Orientalni 17(1), 172-211.

Eilberg-Schwartz, H., 1990, The savage in Judaism: An anthropology of Israelite religion and ancient Judaism, Indiana University Press, Bloomington.

Elliott, J.H., 1990, A home for the homeless: A social-scientific criticism of I Peter, its situation and strategy, with a new introduction, Fortress, Minneapolis.

Elliott, J.H., 1986, 'Social-scientific criticism of the New Testament and its social world: More on method and models', in J.H. Elliott (ed.), Social-scientific criticism of the New Testament and its social world, Semeia 35, pp. 1-33, Scholars Press, Decatur.

Elliott, J.H., 1988, 'The fear of the leer. The evil eye from the Bible to Li'I Abner', Forum $4(4), 42-71$.

Elliott, J.H., 1990, 'Paul, Galatians, and the evil eye', Currents in Theology and Mission $17,262-73$.

Elliott, J.H., 1991, 'The evil eye in the first testament: The ecology and culture of a pervasive belief', in D. Jobling et al. (eds.), The Bible and the politics of exegesis. Essays in honor of Norman K. Gottwald on his sixty-fifth birthday, pp. 147-159, Pilgrim Press, Cleveland.

Elliott, J.H., 1992, 'Matthew 20:1-15: A parable of invidious comparison and evil eye accusation', Biblical Theology Bulletin 22(2), 52-65. doi: 10.1177/014610799202200203

Elliott, J.H., 1994, 'The evil eye and the sermon on the mount. Contours of a pervasive belief in social scientific perspective', Biblical Interpretation 2(1), 51-84. doi: belief in social scientific p
$10.1163 / 156851594 \times 00042$

Elliott, J.H., 1993, What is social-scientific criticism?, Guides to biblical scholarship, New Testament series, Fortress, Minneapolis.

Elliott, J.H., 2000, 1 Peter: A new translation with introduction and commentary, Anchor Bible 37B, Doubleday, Random House, New York.

Elliott, J.H., 2002, 'Jesus was not an egalitarian. A critique of an anachronistic and idealist theory', Biblical Theology Bulletin 32(2), 75-91. doi: $10.1177 / 014610790203200206$

Elliott, J.H., 2003, 'The Jesus movement was not egalitarian but family-oriented', Biblical Interpretation 11(2), 173-210. doi: 10.1163/156851503765661276

Elliott, J.H., 2005, 'Lecture socioscientifique. Illustration par l'accusation du Mauvais Oeil en Galatie', in A. Lacocque (ed.), Guide des nouvelles lectures de la Bible, pp. 141-167, Traduction de Jean-Pierre Prévost, Bayard Éditions, Paris.

Elliott, J.H., 2008a, 'La crítica socio-cientifica: La configuración colectiva y cooperativa de un método', in C. Bernabé \& C. Gil (eds.), Reimaginando los orígenes del cristianismo. Relevancia social y ecclesial de los estudios sobre orígenes del cristianismo. Libro homenaje a Rafael Aguirre en su 65 compleaños, Agora 23, pp. cristianismo. Libro homenaje a Rafael Aguirre en su

Elliott, J.H., 2008b, 'From social description to social-scientific criticism. The history of a society of biblical literature section 1973-2005', Biblical Theology Bulletin 38(1), 26-36. doi: 10.1177/01461079080380010401

Elworthy, F.T., 1958, The evil eye: An account of this ancient and widespread superstition, rev. edn., Julian Press, New York.

Esler, P.F., 1987, Community and Gospel in Luke-Acts, SNTSMS 57, Cambridge University Press, New York.

Esler, P.F., 1998, Galatians, New Testament readings, Routledge, London/New York.

Esler, P.F., 2003, Conflict and identity in Romans, Fortress, Minneapolis.

Esler, P.F., 2006, 'Social-scientific models in biblical interpretation', in P.F. Esler (ed.), Ancient Israel. The Old Testament in Its Social Context, pp. 3-14, Fortress, Minneapolis.

Ford, J.N., 1998,' "Ninety-nine by the evil eye and one from natural causes." KTU 1.96 in its Near Eastern context', Ugarit-Forschungen 30, 201-278.

Gager, J.G., 1975, Kingdom and community: The social world of early Christianity, Prentice-Hall, Englewood Cliffs.

Gifford, E.S., 1958, The evil eye: Studies in the folklore of vision, Macmillan, New York.

Gordon, J.D., 1997, Sister or wife? 1 Corinthians and cultural anthropology, JSNTSup 149, Sheffield Academic Press, Sheffield.

Gowler, D.B., 1991, Host, guest, enemy and friend: Portraits of the Pharisees in Luke and Acts, Emory studies in early Christianity, 2, Peter Lang, New York.

Guijarro Oporto, S., 1998, Fidelidades en conflicto: La ruptura con la familia por causa del discipulado y de la misión en la tradición sinóptica, Plenitudo Temporis 5 , Universidad Pontificia, Salamanca.

Jahn, O., 1855, Über den Aberglauben des bösen Blickes bei den Alten, Berichte der Sächsischen Gesellschaft der Wissenschaften zu Leipzig, Phil. hist. Classe, pp. 28-110 \& 5 plates.

Kloppenborg, J., 2000, Excavating Q: The history and setting of the sayings gospel, Fortress, Minneapolis. 
Malina, B.J., 1981, The New Testament world: Insights from cultural anthropology, John Knox, Atlanta.

Malina, B.J., 1986, Christian origins and cultural anthropology: Practical models for biblical interpretation, John Knox, Atlanta.

Malina, B.J., 1985, The Gospel of John in sociolinguistic perspective, 48th Colloquy of the Center for Hermeneutical Studies in Hellenistic and Modern Culture, ed. $\mathrm{H}$. Waetjen, Center for Hermeneutical Studies, Berkeley.

Malina, B.J., 1995, On the genre and message of Revelation: Star visions and sky journeys, Hendrickson, Peabody.

Malina, B.J. \& Neyrey, J.H., 1988, Calling Jesus names: The social value of labels in Matthew, Foundations and Facets, Social Facets, Polebridge Press, Sonoma.

Malina, B.J. \& Pilch, J.J., 2000, Social-science commentary on the gospel of the Book of Revelation, Fortress, Minneapolis.

Malina, B.J. \& Rohrbaugh, R.L., 1992, Social-science commentary on the synoptic gospels, Fortress, Minneapolis.

Malina, B.J. \& Rohrbaugh, R.L., 1998, Social-science commentary on the Gospel of John, Fortress, Minneapolis.

Maloney, C. (ed.), 1976, The evil eye, Columbia University Press, New York.

Meeks, W.A., 1972, 'The man from heaven in Johannine Sectarianism', Journal of Biblical Literature 91, 44-72. doi: 10.2307/3262920

Meeks, W.A., 1983, The first urban Christians: The social world of the apostle Paul, Yale University, New Haven.

Moxnes, H., 1988, The economy of the kingdom: Social conflict and economic relation in Luke's gospel, Fortress, Philadelphia.

Neyrey, J.H., 1988, An ideology of revolt: John's Christology in social-science perspective, Fortress, Philadelphia.

Neyrey, J.H., 1990, Paul, in other words: A cultural reading of his letters, Westminste John Knox, Louisville.

Neyrey, J.H. (ed.), 1991 The social world of Luke-Acts: Models for interpretation, Hendrickson Publishers, Peabody.

Neyrey, J.H., 1998, Honor and shame in the gospel of Matthew, Westminster John Knox, Louisville.
Noy, D., 1971, 'Evil eye', Encyclopedia Judaica 6, 997-1000.

Petersen, N.R., 1985, Rediscovering Paul: Philemon and the sociology of Paul's narrative world, Fortress, Philadelphia.

Pilch, J.J., 1983, Galatians and Romans, Collegeville Bible Commentary, No. 6 , Liturgical Press, Collegeville.

Pilch, J.J. 2004, Visions and healing in Acts of the Apostles: How the early believers experienced God, The Liturgical Press, Collegeville.

Rakoczy, T., 1996, Böser Blick, Macht des Auges und Neid der Götter: Eine Untersuchung zur Kraft des Blickes in der griechischen Literatur, Classica Monacensia 13, Gunter Narr, Tübingen.

Schoeck, H., 1970, Envy. A theory of social behaviour, Harcourt, Brace \& World, New York.

Seligmann, S., 1910, Der Böse Blick und Verwandtes: Ein Beitrag zur Geschichte des Aberglaubens aller Zeiten und Völker, 2 vols., Hermann Barsdorf, Berlin; reprinted in 1985, 2 vols. in one, Georg Olms Verlag, Hildesheim.

Seligmann, S., 1922, Die Zauberkraft des Auges und das Berufen: Ein Kapitel aus der Geschichte des Aberglaubens, L. Friederichsen \& Co., Hamburg.

Seligmann, S., 1927, Die magischen Heil- und Schutzmittel aus der unbelebten Natur, mit besonderer Berücksichtigung der Mittel gegen den Bösen Blick: Eine Geschichte des Amulett-wesens, Strecker \& Schroeder, Stuttgart.

Snyder, G., 2002, Irish Jesus, Roman Jesus: The formation of early Irish Christianity, Trinity Press International, Harrisburg.

Theissen, G., 1982, The social setting of Pauline Christianity: Essays on Corinth, ed. \& transl. with an Introduction J.H. Schütz, Fortress, Philadelphia.

Theissen, G., 1978, Sociology of early Palestinian Christianity, Fortress, Philadelphia.

Verdoodt, A., 2001, 'L'étude de la Bible d'après l'exégéte-sociologue J.H. Elliott', Recherches Sociologiques 32(1), 143-150.

Waetjen, H.C., 1989, A reordering of power: A socio-political reading of Mark's gospel, Fortress, Minneapolis.

Wilde, J.A., 1974, 'A social description of the community reflected in the gospel of Mark', PhD thesis, Drew University, Madison. 